\title{
HUBUNGAN WAKTU KERJA TERHADAP HASIL KERJA PADA PELAKSANAAN UJI KOMPETENSI PRAKTIK KEJURUAN BIDANG PEMESINAN BUBUT
}

\author{
Khalis K. Adiranti ${ }^{1}$, Wardaya ${ }^{2}$, Purnawan ${ }^{3}$ \\ Departemen Pendidikan Teknik Mesin \\ Universitas Pendidikan Indonesia \\ Jl. Dr. Setiabudhi No. 207 Bandung 40154 \\ khaliskhalifanatama@gmail.com
}

\begin{abstract}
ABSTRAK
Tujuan dari penelitian ini, adalah untuk mengetahui gambaran hubungan waktu kerja terhadap hasil kerja pada uji kompetensi praktik kejuruan bidang pemesinan bubut di SMK Taruna Mandiri Cimahi tahun pelajaran 2013/2014. Metode yang digunakan dalam penelitian ini adalah metode deskriptif korelasional dengan subjek penelitian sebanyak 30 siswa. Data diperoleh melalui observasi langsung terhadap pelaksanaan uji kompetensi praktik kejuruan teknik pemesinan untuk pekerjaan membubut. Jenis proses terdiri atas membubut diameter, membubut panjang, mengebor diameter, membubut alur, membubut ulir, membubut tirus dan mengebor kedalaman. Hasil penelitian menunjukan bahwa tidak terdapat hubungan yang positif dan signifikan antara waktu kerja pemesinan terhadap hasil kerja pada pelaksanaan uji kompetensi praktik kejuruan bidang pemesinan bubut di SMK Taruna Mandiri Cimahi.
\end{abstract}

Kata kunci: waktu kerja, hasil kerja, pemesinan, bubut, uji kompetensi

\section{PENDAHULUAN}

Pelaksanaan uji kompetensi merupakan salah satu standar kelulusan siswa di SMK. Penilaian uji kompetensi di SMK diatur kedalam Peraturan Menteri Pendidikan Nasional (Peremendiknas) Nomor 78 Tahun 2008 tentang ujian nasional dan keputusan BSNP Nomor 1513/BNSP/XI/2008 tentang Prosedur Operasi Standar (POS) Ujian Nasional bahwa mengingat struktur kurikulum SMK mencakup kognitif dan psikomotorik yang meliputi pula aspek afektik (Depdiknas, 2008). Ujian Nasional Kompetensi Keahlian Kejuruan dirancang dalam bentuk teori dan praktek kejuruan (Individual Task).

Tujuan dari penilaian kompetensi adalah untuk menetapkan keberhasilan peserta didik dalam menguasai satu unit kompetensi dengan mengacu kepada standar kompetensi nasional. Standar kompetensi adalah kemampuan yang secara umum harus dimiliki oleh peseta didik (lulusan). Pernyataan yang menggambarkan penampilan suatu kemampuan tertentu secara bulat yang merupakan perpaduan antara pengetahuan dan kemampuan yang dapat diamati dan diukur (Muslich, 2011).

\footnotetext{
${ }^{1}$ Mahasiswa Departemen Pendidikan Teknik Mesin FPTK UPI

${ }^{2}$ Dosen Departemen Pendidikan Teknik Mesin FPTK UPI

${ }^{3}$ Dosen Departemen Pendidikan Teknik Mesin FPTK UPI
} 
Hasil observasi melalui studi dokumentasi yang dilakukan oleh penulis di SMK Taruna Mandiri Cimahi mengenai data lulusan yang bekerja di industri dihitung dari 5 tahun terakhir dimulai dari tahun 2009 hingga tahun 2013. Keterserapan lulusan yang bekerja di industri 47,7\% dan yang lainnya 52,3\%. Lulusan SMK Taruna Mandiri Cimahi yang bekerja di industri masih kecil (Arikunto, 2013). Kemampuan siswa pada uji kompetensi kejuruan masih kurang ditambah dengan peluang kerja di industri terbatas. Hal itu bisa menjadi salah satu faktor yang menjadikan minimnya siswa terserap di dunia industri. Ada beberapa hal lain seperti siswa yang memang ingin melanjutkan ke perguruan tinggi, atau dengan berwirausaha.

Badan Standar Nasional Pendidikan atau BSNP telah menentukan standar penilaian dalam pelaksaan uji kompetensi dalam lembar penilaian ujian praktik kejuruan. Ada beberapa kriteria tertentu dalam penilaian yang merujuk kepada kompetensi yang diharapkan. Meliputi aspek persiapan kerja, proses (sistematika dan cara kerja), hasil kerja, sikap kerja dan waktu. Kelima aspek tersebut menjadi standar acuan penilaian pada proses ujian kompetensi praktik kejuruan. Kelima aspek tersebut, waktu pelaksanaan ujian kompetensi kejuruan dan hasil kerja praktik pelaksanaan ujian kompetensi kejuruan (Mulyasa, 2011). Dimana siswa dituntut agar dapat menghasilkan produk sesuai dengan perencanaan dengan waktu kerja pemesinan yang optimum.

Seorang peserta didik yang akan menjadi operator mesin di industri dituntut mampu menghasilkan produk sesuai dengan perencanaan dengan waktu yang telah ditentukan. Faktor-faktor yang mempengaruhi hasil produk yaitu mesin/perkakas pahat yang digunakan, bahan benda kerja, pemilihan parameter pemotongan, dan operator itu sendiri (Dimyanti dan Mudjiono, 2009). Skill operator meliputi perencanaan waktu kerja yang sesuai dengan standar dan proses pembuatan sesuai dengan perencanaan. Masalahnya apakah siswa SMK yang mengerjakan benda kerja dengan waktu tercepat dapat menghasilkan produk yang sesuai dengan perencanaan ataukah sebaliknya.

Parameter pemotongan untuk pekerjaan pemesinan bubut ada tiga, yaitu kedalaman potong, gerak makan, dan kecepatan potong. Tiga parameter pemotongan tersebut merupakan bagian yang dapat diatur langsung oleh seorang operator pada mesin bubut agar menghasilkan produk sesuai dengan perencanaan. Pemilihan parameter pemotongan ini berhubungan dengan waktu kerja pemesinan dan umur pahat, jika waktu pemotongan terlalu cepat maka pahat akan cepat tumpul begitupun dengan waktu pemotongan yang lama, pahat tidak akan cepat tumpul namun waktu pemesinan 
akan menjadi lama. Sehingga siswa harus benar dalam melakukan perencanaan proses sebelum membubut pada proses uji kompetensi kejuruan bidang pemesinan bubut ini.

\section{METODE PENELITIAN}

Penelitian ini menggunakan metode deskriptif korelasional. Data yang terkumpul pada setiap variabel sehingga menghasilkan temuan berupa tingkat hubungan antara variabel tersebut. Teknik pengumpulan data dilakukan observasi langsung dengan maksud untuk mendapatkan nilai waktu pemesinan dan hasil kerja pada pelaksanaan uji kompetensi praktik kejuruan bidang pemesinan bubut tahun pelajaran 2013/2014.

Populasi dalam penelitian ini adalah seluruh siswa tingkat XII bidang kompetensi Pemesinan di SMK Taruna Mandiri Cimahi tahun pelajaran 2013/2014, yang terdiri dari 120 siswa. Sedangkan sampel yang digunakan dalam penelitian ini terdiri dari 30 siswa dengan teknik sampling insidental sampling, karena waktu pelaksanaan ujian kompetensi praktik kejuruan disekolah yang bersangkutan sudah hampir selesai, jadi diambil data hanya pada satu kelas saja dengan siswa sebanyak 30 siswa.

Analisis data yang dilakukan untuk menganalisis data hasil pengukuran produk hasil kerja pada pemesinan bubut pada proses membubut diameter, mengebor diameter, membubut alur, membubut ulir, membubut panjang, membubut tirus, dan mengebor kedalaman. Adapun pengujian yang dilakukan dalam penelitian ini, meliputi: uji normalitas, uji homogenitas, uji regresi sederhana, perhitungan koefisien korelasi, dan pengujian hipotesis.

\section{HASIL PENELITIAN}

Setelah diperoleh data mengenai waktu kerja dengan hasil kerja pada pelaksanaan uji kompetensi praktik kejuruan bidang pemesinan bubut. Data sudah dianalisis dari berbagai aspek dan disajikan secara ringkas (Tabel 1). Data waktu kerja dan hasil kerja uji kompetensi praktik kejuruan bidang pemesinan tahun pelajaran 2013/2014 berdistribusi normal. Data tersebut diuji pada taraf kesalahan atau taraf signifikansi $(\alpha)$ 5\% dengan menggunakan uji chi kuadrat. Dikarenakan data berdistribusi normal, maka penggunaan statistik parametrik untuk pengujian hipotesis. Uji homogenitas dilakukan dengan uji Bartlett pada variabel X dan Y. Data tersebut diuji dengan taraf signifikansi ( $\alpha$ ) 0,05 dengan derajat kebebasan $(\mathrm{dk})=\mathrm{k}-1$, dan hasil pengujian tersebut menunjukan bahwa kedua kelompok data tersebut homogen. 
Tabel 1. Hasil Analisis Data

\begin{tabular}{|c|c|c|c|}
\hline \multirow{2}{*}{\multicolumn{2}{|c|}{ Data Penelitian }} & \multicolumn{2}{|c|}{ Hasil Uji Kompetensi Keahlian } \\
\hline & & $\begin{array}{l}\text { Waktu kerja } \\
(\mathrm{X})\end{array}$ & $\begin{array}{l}\text { Hasil Kerja } \\
\text { (Y) }\end{array}$ \\
\hline \multirow[t]{2}{*}{ Uji homogenitas } & & \multicolumn{2}{|c|}{$\chi^{2}=0,12557<3,841$} \\
\hline & Kondisi & Homogen & \\
\hline \multirow{2}{*}{ Uji Normalitas } & Nilai $\chi^{2}$ & $\begin{array}{l}\chi_{\text {hitung }}^{2} \leq \chi_{\text {tabel }}^{2} \\
(6,06 \leq 11,07)\end{array}$ & $\begin{array}{l}\chi_{\text {hitung }}^{2} \leq \chi_{\text {tabel }}^{2} \\
(4,54 \leq 11,07)\end{array}$ \\
\hline & Kondisi & Normal & Normal \\
\hline \multicolumn{2}{|l|}{ Uji Regresi Sederhana } & \multicolumn{2}{|c|}{$\hat{\mathrm{Y}}=57,82-0,16 \mathrm{X}$} \\
\hline \multirow{2}{*}{$\begin{array}{l}\text { Perhitungan Koefisien } \\
\text { Korelasi }\end{array}$} & Nilai r & \multicolumn{2}{|l|}{$r=-0,16$} \\
\hline & $\begin{array}{l}\text { Tingkat } \\
\text { Hubungan }\end{array}$ & \multicolumn{2}{|l|}{ Sangat Rendah } \\
\hline \multirow{2}{*}{ Pengujian Hipotesis } & Nilai t & \multicolumn{2}{|c|}{$\mathrm{t}_{\text {hitung }}=0,87 \leq \mathrm{t}_{\text {tabel }}=1,701$} \\
\hline & Kondisi & \multicolumn{2}{|c|}{ Ho diterima dan Ha ditolak } \\
\hline
\end{tabular}

Uji regresi sederhana dilakukan untuk memprediksi hasil kerja uji kompetensi praktik kejuruan (Y) apabila waktu kerja uji kompetensi praktik kejuruan (X) diketahui. Berdasarkan hasil analisis data yang telah dilakukan terhadap waktu kerja dan hasil kerja uji kompetensi praktik kejuruan tahun pelajaran 2013/2014, diperoleh persamaan umum regresi, yaitu: $\hat{Y}=57,82-0,16 X$. Persamaan umum regresi tersebut menunjukkan bahwa terdapat hubungan yang linier antara waktu kerja dengan hasil kerja pada uji kompetensi praktik kejuruan bidang pemesinan bubut. Berdasarkan persamaan tersebut, diketahui bahwa harga koefisien arah regresi linier $b=-0,16$ bertanda negatif, sehingga dapat dinyatakan bahwa setiap bertambahnya waktu kerja pemesinan bubut pada uji kompetensi praktik kejuruan, diprediksi hasil kerja akan mengalami penurunan rata-rata sebesar $-0,16$ point pada setiap tingkatannya.

Perhitungan koefisien korelasi dilakukan untuk dapat mengetahui tingkat hubungan antara waktu kerja dengan hasil kerja. Berdasarkan hasil perhitungan pada analisis data yang telah dilakukan, diperoleh nilai koefisien korelasi sebesar - 0,16 yang berada pada kategori sangat rendah. Sehingga dapat disimpulkan bahwa terdapat hubungan yang sangat rendah antara waktu kerja terhadap hasil kerja pada pelaksanaan uji kompetensi praktik kejuruan bidang pemesinan bubut tahun pelajaran 2013/2014 .

Uji hipotesis dilakukan dengan maksud untuk menguji kebeneran atas hipotesis yang telah diajukan sebelumnya, apakah diterima atau ditolak pada kesimpulan 
akhirnya. Berdasarkan analisa data diketahui bahwa tidak terdapat hubungan yang positif dan signifikan antara waktu kerja dengan hasil kerja pada uji kompetensi praktik kejuruan bidang pemesinan bubut di SMK Taruna Mandiri Cimahi tahun pelajaran $2013 / 2014$.

\section{PEMBAHASAN}

Sebagian kecil siswa yang menyelesaikan waktu diatas rata-rata dan terdapat 5 orang siswa yang masih berada di bawah rata-rata, sedangkan 21 orang siswa berada pada ruang lingkup rata-rata. Secara umum, gambaran pelaksanaan waktu kerja ini menjadi representasi dari hasil pembelajaran praktik pemesinan bubut. Hasil ini menggambarkan bahwa terindikasi terdapat beberapa hal yang mempengaruhi ketidaktercapaian hasil waktu kerja dalam proses pemesinan bubut pada pelaksanaan uji kompetensi praktik (Triyono, 2012).

Pelaksanaan uji kompetensi merupakan sarana evaluasi yang dilakukan pada proses pembelajaran, termasuk didalamnya melaksanakan penilaian proses dan hasil belajar. Evaluasi merupakan salah satu komponen yang penting untuk mengetahui keefektifan pembelajaran. Hasil yang diperoleh dapat dijadikan tolak ukur untuk penyempurnaan program dan proses pembelajaran (Susilana, 2006).

Hasil pencapaian kompetensi untuk aspek waktu kerja pemesinan siswa dapat dikatakan sudah cukup baik dengan melihat sekitar $80 \%$ siswa berada pada interval kategori sangat cepat hingga cukup cepat. Namun sekitar $20 \%$ siswa masih berada kategori yang kurang cepat. Hal ini mengindikasikan ada beberapa faktor yang mempengaruhi ketidak tercapaian penilaian waktu kerja dimana siswa masih menggunakan alat alat penunjang bersama-sama. Sehingga memakan waktu yang cukup lama. Siswa belum paham membaca alur proses pengerjaan pada uji kompetensi yang tertuang pada gambar. Sehingga siswa kebingungan memulai pengerjaan dari mana, siswa juga tidak memperhatikan parameter pemotongan, kedalaman potong, kecepatan potong, dan putaran mesin.

Pada komponen waktu pemesinan ini terdiri dari beberapa aspek. Optimasi proses pemesinan melalui jumlah menit kerja di dalam dunia industri. Kegiatan operator yang produktif pada proses pemesinan membubut. Meliputi waktu aktif memotong (mengawasi mesin yang bekerja) sebesar 36,2\%. Waktu mesin yang tidak memotong atau nonproduktif (memasang benda kerja, penyiapan, pengakhiran, pengambilan 
produk) sebesar 13,4\%, waktu mengganti pahat sebesar 1,9\% dan waktu mengukur benda kerja (pada atau di luar mesin) sebesar 5,6\%. Dalam aspek waktu kerja pemesinan ini jika diaplikasikan dalam pelaksanaan uji kompetensi praktik kejuruan ini adalah untuk mengukur keterampilan siswa dalam mengatur waktu pekerjaan pemesinan.

Hanya sedikit siswa yang berada pada kategori sangat baik, 3 siswa yang berada pada kategori kurang baik, dan 23 siswa berada pada ruang lingkup rata-rata. Selain itu, dibuat langkah dengan cara distribusi penilaian pada setiap proses pengerjaan pada pelaksanaan uji kompetensi praktik kejuruan. Hal tersebut agar dapat mengetahui sejauh mana tingkat keberhasilan siswa.

Keterampilan siswa dalam melakukan setiap jenis proses pengerjaan pada uji kompetensi praktik kejuruan bidang pemesinan bubut ini masih kurang baik dan maksimal. Sebesar $71,2 \%$ yang mendapatkan skor nol untuk setiap jenis proses pengerjaannya. Secara umum keberagaman yang dicapai ini terindikasi ada beberapa yang mempengaruhi ketidaktercapaian hasil kerja. Dimana siswa tersebut kurang memperhatikan parameter pemotongan, kecepatan potong, kedalaman potong, putaran mesin, dan juga umur pahat.

Mesin produksi presisi (tepat, atau keterulangan tinggi) biasanya mempunyai karakteristik variabilitas (keadaan bervariasi kecenderungan berubah-ubah) proses yang kecil namun sebaliknya mesin produksi yang tidak presisi (serta tidak otomatis) cenderung untuk menghasilkan produk dengan variabilitas yang besar (Rochim, 2001). Hal ini yang menyebabkan kualitas produk hasil kerja menjadi tidak maksimal dan sering tidak diperhatikan oleh siswa. Kecepatan potong yang terlalu rendah akan mengakibatkan produk yang terlalu kasar. Dalam keadaan seperti pemotongan dengan interupsi atau adanya beban kejut yang dilakukan pada kecepatan potong yang terlalu rendah dapat memperpendek umur pahat (Rochim, 1993). Hal ini yang menyebabkan kualitas produk hasil kerja menjadi kurang baik. Pahat yang digunakan tidak sesuai dengan pekerjaan yang dilakukan, yang dipandang dari segi materialnya maupun geometriknya (bentuk dan sudut pahat). Berdasarkan fakor tersebut, maka seorang operator harus bisa merencanakan atau mengoptimasi proses pemesinan agar mendapatkan kualitas produk hasil kerja yang sesuai.

Tiga parameter utama pada setiap proses bubut adalah kecepatan putar, gerak makan, dan kedalaman potong. Faktor yang lain seperti bahan benda kerja dan jenis 
pahat sebenarnya juga memiliki pengaruh cukup besar, tetapi ketiga parameter diatas adalah bagian yang bisa diatur oleh operator langsung pada mesin bubut (Widarto, 2008).

Besar hubungan antara waktu kerja dengan hasil kerja pada pelaksanaan uji kompetensi praktik kejuruan bidang pemesinan bubut. Hubungan ini diperoleh berdasarkan hasil analisis data mengenai uji koefisian, uji regresi dan uji hipotesis. Diperoleh persamaan umum regresi linier, yaitu $\hat{Y}=57,82-0,16 X$. Persamaan umum regresi linier tersebut menunjukkan bahwa semakin bertambah waktu kerja. Diprediksi hasil kerja uji kompetensi praktik kejuruan akan mengalami penurunan rata-rata sebesar 0,16 poin setiap tingkatnya. Selanjutnya adalah harga koefisien korelasi, diperoleh harga $\mathrm{R}=0,16$, harga koefisien korelasi tersebut berada pada kategori sangat rendah. Diartikan bahwa terdapat hubungan antara waktu kerja dengan hasil kerja namun hubungan tersebut sangat rendah. Selanjutnya dari hasil tersebut, dilakukan uji hipotesis agar dapat mengetahui apakah hipotesis yang diajukan diterima atau ditolak. Hasil perhitungan yang diperoleh harga $t_{\text {hitung }}$ lebih kecil daripada harga $t_{\text {tabel }}$, dari penjelasan tersebut. Artinya tidak terdapat hubungan yang positif dan signifikan antara waktu kerja dan hasil kerja pada pelaksanaan uji kompetensi praktik kejuruan bidang pemesinan bubut.

Tabel 2. Kontingensi waktu kerja terhadap hasil kerja

\begin{tabular}{ccccccc}
\hline \multirow{2}{*}{ Hubungan/Kategori } & \multicolumn{5}{c}{ Hasil Kerja } & \multirow{2}{*}{ TOTAL } \\
\cline { 3 - 6 } & Sangat Baik & Baik & Cukup Baik & Kurang Baik & \\
\hline \multirow{3}{*}{ Waktu } & Cepat & 0 & 2 & 2 & 0 & 4 \\
Kerja & 2 & 4 & 4 & 1 & 11 \\
& Cukup Cepat & 2 & 2 & 6 & 0 & 10 \\
& Kurang Cepat & 0 & 2 & 1 & 2 & 5 \\
\multicolumn{2}{c}{ TOTAL } & 4 & 10 & 13 & 3 & 30 \\
\hline
\end{tabular}

Hubungan ini merupakan hubungan yang moderat, artinya hubungan tersebut cenderung berada di tengah dimana waktu kerja yang berada pada kategori cepat bisa mendapatkan hasil yang baik dan cukup baik, dan pada kategori cukup cepat bisa mendapatkan hasil yang cukup baik. Ada beberapa faktor yang biasanya tidak diperhatikan oleh siswa pada pelaksanaan uji kompetensi praktik kejuruan bidang pemesinan bubut ini.

Biasanya siswa tidak memperhatikan parameter dalam pemotongan yang diantaranya kedalaman potong (deep of cut) dan putaran mesin yang berdampak pada 
umur pahat. Semakin tinggi harga Vc, maka semakin pendek umur pahat, atau semakin kecil harga Vc, maka semakin panjang umur pahat (Makmur, 2010). Untuk memperoleh umur pahat yang lebih bertahan lama maka kecepatan potong dipilih pada harga yang lebih kecil. Apabila umur pahat ini tidak diperhatikan, akan berdampak pada hasil produk yang kurang baik.

Implikasi dari pembahasan hasil penelitian yang dilakukan dalam rangka meningkatkan mutu kompetensi siswa sebagai calon operator di industri pemesinan. Kemampuan siswa dalam kegiatan praktik perlu ditingkatkan, salah satunya adalah dalam perencanaan proses untuk aspek waktu kerja. Agar siswa dapat mengetahui waktu standar untuk menghasilkan produk yang sesuai perencanaan, dan siswa mampu memaksimalkan kemampuan untuk melakukan pekerjaan dengan baik.

\section{KESIMPULAN}

Kesimpulan penelitian ini, sebagai berikut waktu kerja rata-rata pada pelaksanaan uji kompetensi praktik kejuruan bidang pemesinan bubut yaitu 236,1 menit. Skor ratarata hasil kerja pada pelaksanaan uji kompetensi praktik kejuruan bidang pemesinan bubut yaitu 9,33. Ada hubungan yang positif dan signifikan antara waktu kerja dengan hasil kerja pada pelaksanaan uji kompetensi praktik kejuruan bidang pemesinan bubut walaupun kategorinya sangat rendah.

\section{DAFTAR PUSTAKA}

Arikunto, S. (2013). Dasar-dasar Evaluasi Pendidikan. Jakarta: Bumi Aksara.

Depdiknas. (2008). Petunjuk Teknis Penilaian Hasil Belajar Sekolah Menengah Kejuruan. Jakarta: Depdiknas.

Dimyanti dan Mudjiono. (2009). Belajar dan Pembelajaran. Jakarta: Rineka Cipta.

Direktorat Pembinaan SMK. (2013). Revisi Pedoman Penyelenggaraan Uji Kompetensi Keahlian (UKK) SMK Tahun Pelajaran 2012/2013. Jakarta: Kemendikbud.

Makmur, H. (2010). Analisa Pengaruh Kecepatan Potong Proses Pembubutan Baja Amutit K 460 Terhadap Umur Pahat HSS. Jurnal Austenit. 1 (3), hlm. 8-20. Politeknik Negeri Sriwijaya.

Mulyasa, E. (2011). Kurikulum Tingkat Satuan Pendidikan. Bandung: PT. Remaja Rosdakarya. 
Muslich, M. (2011). KTSP Pembelajaran Berbasis Kompetensi dan Kontekstual. Jakarta: Bumi Aksara.

Permendiknas. (2008). Peraturan Menteri Pendidikan Nasional Republik Indonesia Nomor 78 Tahun 2008 tentang Ujian Nasional dan Keputusan BSNP dalam Prosedur Operasi Standar (POS) Ujian Nasional.

Rochim, T. (1993). Teori dan Teknologi Proses Pemesinan. Bandung: Lab. Teknik Produksi Jurusan Teknik Mesin FTI-ITB.

Rochim, T. (2001). Spesifikasi, Metrologi, \& Kontrol Kualitas Geometrik. Jilid 1. Bandung: ITB.

Sanjaya, W. (2011). Pembelajaran dalam Implementasi Kurikulum Berbasis Kompetensi. Jakarta: Kencana.

Susilana, R. (2006). Kurikulum dan Pembelajaran. Bandung: UPI Press.

Triyono, E (2012). Potret Sekolah Kejuruan. Penelitian di Jurusan Teknik Elektro Politeknik Negeri Semarang: Jurnal Teknis. Volume 7. Nomor 2.

Widarto. (2008). Teknik pemesinan jilid 1. Jakarta: Departemen Pendidikan Nasional 